\title{
Welfare as an indicator of quality of life of the population
}

\author{
Aizhan Assilova ${ }^{1, *}$, Gulnara Baimakhambetova ${ }^{2}$, Zhanar Mukhametzhanova ${ }^{1}$, Akmaral \\ Mukasheva $^{1}$ \\ ${ }^{1}$ Al-Farabi Kazakh National University, al-Farabi Ave. 71, 050040 Almaty, Kazakhstan \\ ${ }^{2}$ Kazakh National Conservatory, Abylai-Khan ave., 86, 050000 Almaty, Kazakhstan
}

\begin{abstract}
National welfare refers to very complex manifestations of socioeconomic reality that require the identification of qualitative certainty by determining its properties, elements and structure. The development of national welfare as a multi-faceted and objective process requires an expanded theoretical and methodological approach to its research, integrating Western and domestic welfare theories, taking into account the interrelated transformation of the categories of individual, economic and social welfare, material and national wealth, and the level and quality of life. The article discusses theoretical comments on the concept of welfare and the importance of improving it. This article defines the main factors of socioeconomic inequality, fully classified depending on the scope of impact on the macro level, micro level, individual level, depending on the economic, social, geographical, political, demographic, and psychological levels. The risks that occurred at a low level of welfare are described in detail. Establishing the relationship of the categorical apparatus in the system of improving the welfare of the population allowed us to Supplement the concept of the welfare of the population. At the present stage, the main threats to reduce the welfare of the population in Kazakhstan have been identified. The article discusses the importance of achieving the general welfare of citizens and overcoming poverty in the development strategy of modern states. The main conclusions of the article can be used to further study the categorical apparatus of welfare, as well as to develop proposals for improving the mechanisms of its increase.
\end{abstract}

\section{Introduction}

Since the formation of economic theory as a science, special attention has been paid to the study of welfare problems. The welfare economy emerged as an independent internal branch of the neoclassical trend. The basis of its origin was the works of A. Smith, D. Riccardo, K. Marx, and L. Walras. Welfare is the interaction of physical and public interests that provide wealth and contribute to reducing poverty, and contribute to the growth of the welfare of the population and the state. From the authors' point of view, welfare also characterizes the

\footnotetext{
* Corresponding author: aijan1910@mail.ru
} 
quality of people's lives. Welfare can be both personal and public. Public authorities are called upon to ensure public welfare in the country. They should be responsible for the socalled degree of provision of the population with life benefits. Quality of life benefits for the population increases social quality of life and increased life expectancy, reduced mortality, etc.

In the economic literature over the past two decades, the relevance of the study of problems related to the level of welfare of the population has increased. The relevance of the study of the topic is due to the identification of factors that caused the decline in the welfare of the population. Therefore, first of all, it is necessary to consider and study it taking into account its specific features. In addition, the importance of this topic is increased by the fact that the economic and social conditions of the population can play a significant role in the development of market relations and transformations in the socio-economic sphere.

In his message to the people of Kazakhstan dated October 5, 2018, «Increasing the welfare of Kazakhstan citizens: improving the quality of income and life», N. Nazarbayev noted that «the welfare of citizens, first of all, depends on stable growth of income and quality of life» [1].

He drew attention to the need for a broader approach to the meaning of the concepts of the welfare of the nation, ensuring not only success, but also the basic benefits of life, improving working conditions, etc. The welfare of Kazakhstan depends on overcoming the trends of economic decline and initiating dynamic economic growth.

\section{Results and Discussion}

The genesis of the theoretical concepts of the study of national welfare in conjunction with economic development allows to define the features of the resource approach and neoclassical classics and modern evolutionary and integrative theories of institutional change, theories of socioeconomics.

The first attempts to consider and evaluate the role of national welfare in the classical economic school were made by leading representatives of T. Malthus, D. Ricardo, A. Smith, and J.S. Mill.

Modern researchers who have made significant contributions to the study of material foundations and benefits in society, George J. Borjas., Schwartz H. M., A. Pigou, V. Pareto, and others in works on the problems of the value of goods, the emergence of wealth, its distribution, and the conditions for the emergence of market equilibrium conditions, as determining the objectively necessary conditions for its development and all members of society. In the Russian scientific literature, this story is presented in the works of A. Shevyakov, V. F. Mayer, and others.

Welfare is a broad concept that is a complex socio-economic phenomenon that unites and encompasses the standard of living, the image and quality of the population, and the provision of goods necessary to meet the material and spiritual needs of the population.

To justify the relevance of the research topic and determine the role of higher education development in the economy and society, we used the works of such foreign authors As G. Sidzhvik, R. F. Gataullin, G. R. Yuldasheva, A. N. Klimonov. A. Shevyakov studies the inequality in which it is possible to fully realize the potential of the economically active population, and the remaining residents are provided with an acceptable level of living.

The theme of knowledge-based economy was mentioned in researches R.Sagiyeva et al. A high-end economy is the creation of new, artificial energy and artificial intelligence and their use in all sectors of the economy. In addition, a knowledge-intensive economy is a largescale use of scientific developments, a new content of labor and the attitude of all its participants to it. A high-tech economy is born and is able to develop in a social environment with a sufficient level of intellectual development of society[2]. 
At present, an approach to welfare has been developed from the point of view of the material and spiritual spheres. In this regard, it can be explained as a socio-economic category that includes not only a set of quantitative economic indicators that determine the standard of living of a well-off person, but also qualitative characteristics that determine his satisfaction with the quality of his life. Welfare includes a system of components: income and consumption; state social guarantees and paid services, Social security and social protection. It can be reflected in the relationship between welfare objects and welfare subjects and in the nature of relations between them.

The objects of welfare are economic goods: clothing, food, education, health, etc., noneconomic goods: sunlight, water, air, communication with other members of society, achieving a favorable economic climate, etc., material goods (food, clothing, furniture, appliances, etc.) and non-material goods (education, training, information, etc.), collective, mixed, public goods. Subjects of welfare are individuals, households, social groups, and the population (society) as a whole. Subjects of welfare participate not only as consumers of goods, but also in the process of their creation, distribution and exchange. The problem of welfare is based on solving bilateral problems-achieving the highest possible level of satisfaction of the population's needs with the effective use of all types of economic resources and maintaining justice in society [3].

It is necessary to consider the welfare of the population in relation to all phases of the reproduction cycle and the complex of social relations that arise in the process of production, distribution, exchange and consumption of material and non-material goods and services.

The initial structural proposal of the national welfare system is its functional structure. National well-being is determined not only by the cost of success and life, but also by the state of the entire infrastructure of life support and human activity. The main structural and functional elements of national welfare, in addition to income, are: ecology (nature, clean air, water, land, healthy food), health, education, housing, job security, development of the transport system, personal security, conditions and opportunities for creative work. If earlier in the context of economic development the main emphasis was placed on material production, today it is created in the production of conditions that ensure a decent life, its level and quality. A broad understanding of national welfare, as a combination of objective living conditions and a well-being subjective perception, is an objective basis for the distribution of components United in the functional structure of the life support system, as the full and degree of development of the entire complex of needs and interests of people who have arisen in various forms of activity and with life benefits.

They should be responsible for the extent to which the population is provided with the benefits of life. Quality of life benefits for the population will increase the social quality of life and resulting in increased life expectancy, reduced mortality etc. On the one hand, welfare in society can be considered as a set of personal welfare that differ in the value parameters of each of us. In this regard, the criteria for achieving public welfare are generally averaged. On the other hand, welfare depends both on the biological and social nature of a person and on the objective side of inequality in the distribution of income and wealth under private ownership. The question arises about the need to create a mechanism for effective creation, distribution and consumption of goods by the state in a highly competitive environment for resources among people, for jobs, for goods and services, and for a more dignified life [4].

The study of the diversity of welfare concepts makes it possible to determine its main components (Fig.1).

The article used factor analysis. The main factors of socio-economic differentiation of the population that contribute to the improvement of welfare are provided.

One of the main factors affecting welfare is the level of income of the population. The level and quality of education is also important. 


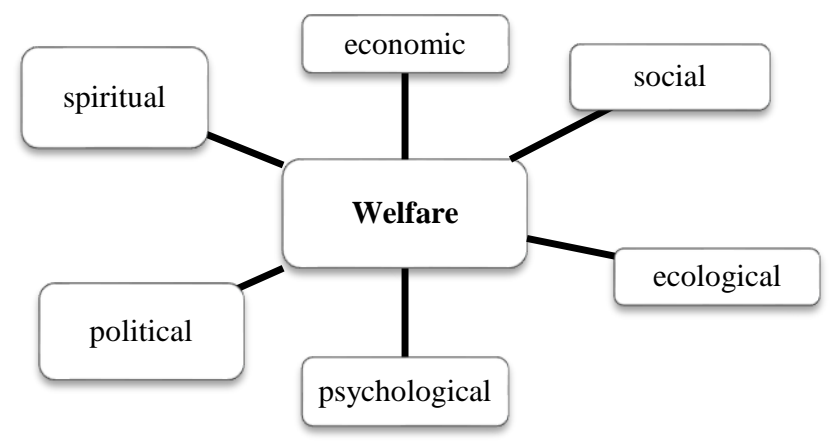

Fig. 1. The key elements of welfare (Compiled by the author on the basis of literature [5])

The quality of education becomes the most important factor in the competitiveness of goods produced by the employee and the product of each person as a subject of production and market relations. The next factor is geographical. The level of welfare depends on it. This land and conditions of population in different regions and areas of the country, respectively the income level, climatic conditions, consumption levels, cost of living, etc. due to the impossibility of the same [5]. Another important factor is demographic. The demographic situation of society is an important area of industrial and social policy. The health of a nation is directly linked to the individual well-being of citizens, the quality of the environment, and individual and collective security. Factors that affect the welfare of the population can be divided as follows:

Table 1. The main factors of the population's welfare.

\begin{tabular}{|c|c|c|}
\hline Classification mark & Name of the factor & The main characteristics \\
\hline \multirow{7}{*}{$\begin{array}{l}\text { By the field of } \\
\text { formation }\end{array}$} & economical & $\begin{array}{l}\text { The level of production, the level of economic } \\
\text { growth and development, the nature of the } \\
\text { distribution of wealth, income levels, inflation }\end{array}$ \\
\hline & social & $\begin{array}{l}\text { Social structure of society, national peculiarities of } \\
\text { population, consumer preferences }\end{array}$ \\
\hline & demographic & $\begin{array}{l}\text { Population, sex and age composition, family size } \\
\text { and composition }\end{array}$ \\
\hline & $\begin{array}{l}\text { scientific-technical } \\
\text { and innovative }\end{array}$ & $\begin{array}{l}\text { STP achievements, Level of scientific and technical } \\
\text { development, volume of research developments, } \\
\text { degree of implementation of innovations and } \\
\text { information technologies, scientific and technical } \\
\text { activities, innovations, level of accessibility of } \\
\text { information technology results }\end{array}$ \\
\hline & political & $\begin{array}{l}\text { The nature of the socio-economic policy of the } \\
\text { state, the costs of the state for the social sphere }\end{array}$ \\
\hline & ecological & $\begin{array}{l}\text { Level of environmental pollution, mechanisms of } \\
\text { regulation of wildlife management, provision of } \\
\text { preservation of nature and environment }\end{array}$ \\
\hline & $\begin{array}{l}\text { natural-geographical } \\
\text { and climatic }\end{array}$ & $\begin{array}{l}\text { Features of natural and geographical location of the } \\
\text { territory, availability of natural resources, features } \\
\text { of geopolitical location, features of climate zone }\end{array}$ \\
\hline \multirow[t]{2}{*}{$\begin{array}{l}\text { By the nature of the } \\
\text { impact }\end{array}$} & directly & $\begin{array}{l}\text { Income level, number of benefits produced, level of } \\
\text { development of production, nature of income } \\
\text { distribution, socio-economic policy of the state }\end{array}$ \\
\hline & indirectly & Consumer preferences \\
\hline
\end{tabular}




\begin{tabular}{|l|c|l|}
\hline $\begin{array}{l}\text { By the direction of } \\
\text { impact }\end{array}$ & industrial & Level of development of production \\
\cline { 2 - 3 } & consumption & $\begin{array}{l}\text { The number of consumers, their features, the level } \\
\text { of revenue }\end{array}$ \\
\hline $\begin{array}{l}\text { By measurement } \\
\text { possibles }\end{array}$ & quantity & Income level, demographics, output, price level \\
\cline { 2 - 3 } $\begin{array}{l}\text { By form of } \\
\text { dependence }\end{array}$ & $\begin{array}{l}\text { Social structure of society, social and economic } \\
\text { policy of the state, condition of productive forces }\end{array}$ \\
\cline { 2 - 3 } & $\begin{array}{l}\text { Income, labor productivity, employment, fair } \\
\text { income, health, education, and access to } \\
\text { information technology. }\end{array}$ \\
\hline Note - [7] compiled by the author on the basis of literature \\
\hline \multicolumn{2}{|l|}{ back } \\
\hline
\end{tabular}

The degree of welfare consists of two categories: wealth and poverty. Therefore, without studying the wealth and poverty of the population, it is impossible to consider such an economic category as well-being. Poverty and wealth are associated with the manifestation of socio-economic inequality, its degree can also characterize the level of welfare of the state. Socio-economic inequality should be considered together with indicators of the population's well-being, such as the level and differentiation of income, as well as the level and quality of life of the population [8]. Socio-economic imbalance refers to differences in the provision of material goods between people, families, social groups, and the ability to meet their needs, which are based on income differentiation [9]. The increase in the socio-economic gap between members of society is associated with unequal social exchanges. The presence of a situation that exceeds the permissible level of inequality leads to large differences in the standard of living of individual groups of society [10]. This leads to social tension, the determinants of the emergence and development of social conflicts, stability of the social system, i.e., deterioration in national security.

The history of socio-economic inequality is largely related to the disappearance of primitive construction, the development of society, and the emergence of the first economic relations. The variety of factors that cause socio-economic inequality can be represented as groups in figure 2 and table 2.

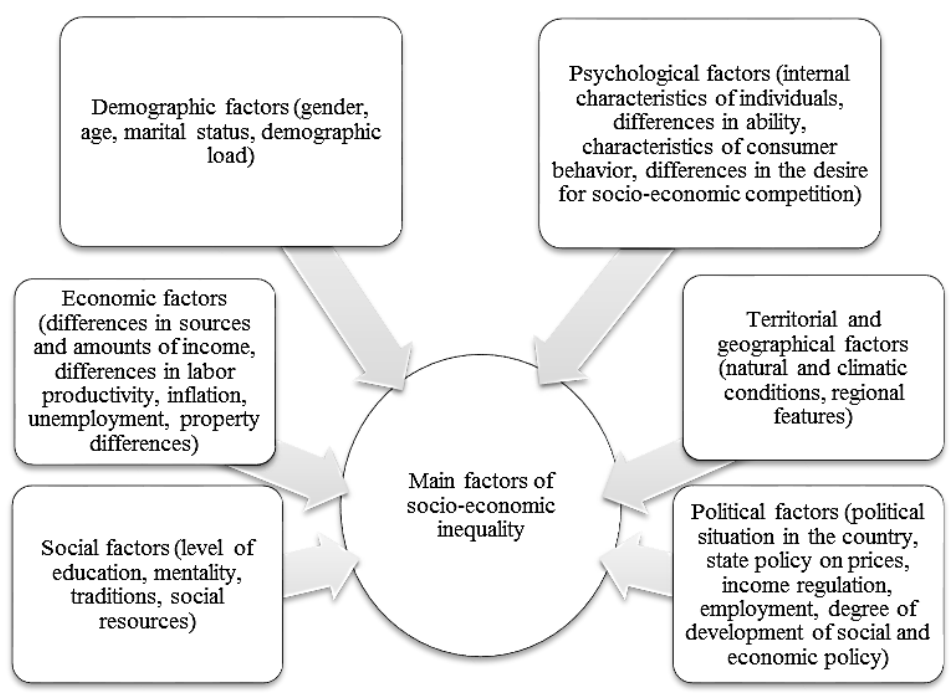

Fig. 2. The main factor of social and economic differentiation of the population (Compiled by the author on the basis of literature [11]) 
Socio-economic inequality is defined as the difference between the ability of people and social groups to provide material goods and meet their needs, which is based on the differentiation of income of the population. The degree of inequality of the population is the result of a complex interaction of economic, political, social, demographic, geographical, psychological and other factors. All these factors are interrelated and interdependent.

It is obvious that normal and excessive inequalities affect not only the consequences of a number of causes, but also the development of regions. First of all, they affect the standard of living and well-being of the population, as well as the quality of human capital. Excessive inequality reduces opportunities for obtaining the necessary knowledge, maintaining health, and obtaining life satisfaction. It disrupts the motivation to work and reduces its productivity. This helps to preserve the low level of real income in the respective regions, which supports excessive inequality in accordance with the resulting dependence [12]. Thus, a limited circle of poverty is created and modernized.

The division of inequality into normal and excess is essential. Moderate inequality is characterized by an excess due to the distribution of income between the segments of the population that are actively involved in economic processes, and low incomes of the same segments of the population that do not have a significant impact on macroeconomic changes (at least in the short term). These include groups of people who live off social transfers and home production, or who work in sectors of the economy that depend on government funding and are depressed or underserved in the current environment. At the same time, excessive inequality is characterized by the excess of the General inequality over the normal inequality. It shows the inability of society to provide a favorable standard of living for groups of the population that need equal use of the economic potential and social support for all ablebodied groups of the population. Normal inequality is directly related to processes in the economy, and excessive inequality is only indirectly related to them-it depends on the stability of society to poverty and institutional conditions.

Normal inequality is not only acceptable, but also in the social part it creates powerful incentives for economic dynamics, and at the same time does not harm the social and political stability of society. Excessive inequality constrains economic growth and threatens sociopolitical stability [13].

Consider the factors of socio-economic inequality at the macro, micro, and individual levels. Economic factors at the macro level: the level of socio-economic development of the state (region), the economic potential of the state, socio-economic policy, scientific and technical progress, technology development, production level, inflation, the presence of crisis situations, tax policy, differentiation of wages, general approaches to wage formation; at the micro level: the main activities of the enterprise/organization, the type of enterprise, the organization's policy for working with personnel, ways of forming the remuneration system, the technical equipment of the enterprise, competitiveness, form of ownership; at the individual level: the initial capital of the individual, the availability of property, labor productivity, investment opportunities, personal qualities of the individual, ability, level of knowledge.

Political factors at the macro level: state policy, the general course of the state, the development of socio-economic policy, the social belonging of the state to the social type.

Geographical factors at the macro level: geographical location, natural resources, natural and climatic conditions; at the micro level: the location of the enterprise; individual level: the place of residence of the individual.

Social factors at the macro level: the level of education, health systems in the country, the general system of values of the population, traditions, moral values; at the individual level: the level and quality of knowledge obtained, the combination of circumstances, success, professionalism, type of profession, social status, skill level, level of professional competence. 
Psychological factors at the individual level: personal qualities, abilities and desires of people, the desire to achieve certain goals, ambition, mobility, life position, consumer behavior.

Demographic factors at the macro level: demographic load, mortality, birth rate, population growth, population composition; at the individual level: gender, age, nationality, family affiliation, number of children in the family [15].

Table 2. Threats arising in a state with a low level of population welfare.

\begin{tabular}{|c|c|}
\hline Risks & Characteristics of risks \\
\hline $\begin{array}{l}\text { Instability in society, social } \\
\text { tension }\end{array}$ & Probability of social conflicts, upheavals, increase in crime \\
\hline $\begin{array}{l}\text { Deterioration of the } \\
\text { demographic situation }\end{array}$ & $\begin{array}{l}\text { Excessive socioeconomic inequalities that lead to poverty and } \\
\text { poverty, have a negative impact on births and increase the } \\
\text { mortality rate, reduce the life expectancy of the population, and } \\
\text { reduce the ratio of workers to the number of retirees. }\end{array}$ \\
\hline $\begin{array}{l}\text { Reduction of potential } \\
\text { possible indicators, such as } \\
\text { insufficient economic growth, } \\
\text { GRP, GDP, GNP }\end{array}$ & 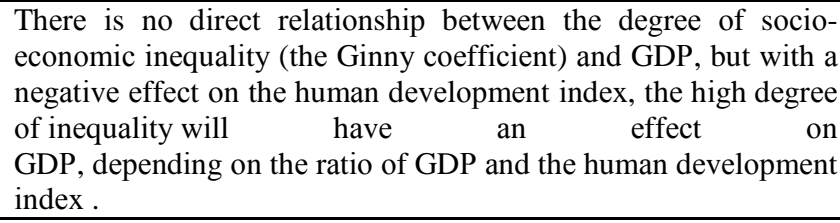 \\
\hline $\begin{array}{l}\text { Reduce the level of potential } \\
\text { development of human capital }\end{array}$ & $\begin{array}{l}\text { The higher the socioeconomic inequality and poverty, the higher } \\
\text { the education, the availability of health services, the mismatch of } \\
\text { food intake with the medical standards of the population, which } \\
\text { adversely affects the level of health; Citizens who are at or beyond } \\
\text { the poverty line may experience depression, slowing down, } \\
\text { insanity, and depression which may reduce their desire to get out } \\
\text { of the situation and the development of socially significant } \\
\text { diseases. }\end{array}$ \\
\hline $\begin{array}{l}\text { A small number of middle } \\
\text { classes }\end{array}$ & $\begin{array}{l}\text { One of the foundations of the middle-class state's stability is its } \\
\text { intellectual value, economic benefit from taxation, progress and } \\
\text { development in the country, small business development, and } \\
\text { more. influences }\end{array}$ \\
\hline $\begin{array}{l}\text { Small investment, innovative } \\
\text { activity }\end{array}$ & $\begin{array}{l}\text { The high degree of inequality that creates the situation for which } \\
\text { the majority of the population belongs to the poor adversely affects } \\
\text { the potential investment, innovative scientific potential of the } \\
\text { state. }\end{array}$ \\
\hline
\end{tabular}

The low level of welfare of the population threatens the stability of the state:

- socio-political threats (aggravation of social contradictions, increase in crime, growth of protest against the government, the threat of a coup);

- economic threats (slowdown in economic growth, decrease in economic activity, decrease in population, increase in budget expenditures for social programs);

- demographic risks (reduced life expectancy and birth rate, population decline due to the deterioration of the level of education of the population);

- information and technological threats (reduction of the level of development and dissemination of technologies, development of digital and information inequality due to difficulties in accessing information and technologies by a part of the population).

Among the phenomena that negatively affect well-being, we distinguish excessive socioeconomic inequality and inefficient social policy of the state. State policy should be aimed at improving the welfare of citizens in all its manifestations, that is, to overcome these negative categories and their consequences [16]. 


\section{Conclusion}

The current stage of world economic and social development is characterized by a significant impact on digitalization. As a new trend in world social development that has replaced informatization and computerization, it is characterized by the following - based on a digital presentation of information, which, on the scale of economic and social life of both a single country and the whole world, leads to an increase in the efficiency of the economy and an improvement in the quality of life [17, 18, 19].

For the welfare of the population in Kazakhstan, the following current risks can be identified: rising inflation; a decrease in the tenge exchange rate; a decrease in the cost of oil; and an increase in unemployment.

High levels of socio-economic inequality, unfair income distribution and poverty negatively affect economic and demographic processes, are a serious obstacle to human development and sustainable economic growth, will limit the development of the state, and generate and exacerbate social contradictions.

Excessive socio-economic inequality is one of the most important threats to the life of the state, contributing to the emergence of negative phenomena such as begging and poverty.

The establishment of the relationship of the categorical apparatus in the system of social welfare to supplement the concept of welfare with the following interpretation: «welfare is a stable situation is reached at the expense of optimal public policy, creating adequate conditions to modern conditions of development of society for the normal needs of the population, characterized by the absence of excessive, unfair inequality, reducing poverty».

There are various approaches related to state intervention in economic regulation. At the same time, it is obvious that overcoming poverty and regulating socio-economic inequality is impossible without state intervention. Therefore, the directions of social and economic policy chosen by the state should be aimed at eliminating excessive inequality, supporting and adapting vulnerable segments of the population.

Achieving optimal welfare of the state's population is impossible without state intervention in the regulation of the market economy, the implementation of social and economic policies, and the application of social programs. Thus, improving the welfare of the population should be the goal of improving the socio-economic policy of the state and other areas of its activity.

\section{References}

1. Message of the President of the Republic of Kazakhstan N. Nazarbayev to the people of Kazakhstan «Increasing the welfare of Kazakhstan people: improving the quality of income and life» (2018)

2. R. Sagiyeva, A. Zhuparova, R. Ruzanov, R. Doszhan, A. Askerov, Entrepreneurship and Sustainability Issues, 6 (2), 711-728 (2018). DOI: 10.9770/jesi.2018.6.2(17)

3. R. Gataullin, G. Yuldasheva, Bulletin of VEGU, 2, 7-17 (2008)

4. H. Schwartz, Politics \& Society, 40 (1), 35-58 (2012)

5. 4.O. Prokhorova, Problems of economy and management, 5 (1), 133-136 (2016)

6. S. Dorosh, Social welfare as a factor in the formation of a new economy, 176 (2010)

7. L. Ayala, E. Barcena-Martin, The Journal of Economic Inequality, 16 (1), 41-59 (2018)

8. R. J. Lilford, The lancet, 559-570 (2016)

9. A. Klimonova, Socio-economic phenomena and processes, 11 (12), 60-67 (2016)

10. G. J. Borjas, Research in Economics, 7 (1), 143-157 (2016)

11. C. P. Chambers, H. Takashi, Journal of Economic Theory, 147 (5), 1818-1849 (2012)

12. L. Kostyleva, ITSED RAS, 223 (2011) 
13. V. Kizhikina, Bulletin of the Tomsk University of Economics series, 1 (17), 74-80 (2012)

14. E. Lazareva, National well-being as an integrated resource of innovation-oriented economic development: theoretical and methodological aspect (Southern Federal University Press, Rostov-on-Don, 2009)

15. Kh. Gizatullin, Journal of Economic Theory, 1, 5-26 (2006)

16. K. Kosarev, European journal of social Sciences, 1-2 (52), 75-79 (2015)

17. S. Ziyadin, B. Ermekbaeva, G. Supugaliyeva, R. Doszhan, Proceedings of the 31st International Business Information Management Association Conference, IBIMA 2018: Innovation Management and Education Excellence through Vision 2020, 20092017 (2018)

18. S. Ziyadin, R. Doszhan, A. Borodin, A. Omarova, \& A. Ilyas, E3S Web of Conferences, 135, 04022 (2019) DOI: 10.1051/e3sconf/201913504022

19. S. Ziyadin, R. Doszhan, G. Saparova, A. Omarova, Proceedings of the 32nd IBIMA 2018 - Vision 2020: Sustainable Economic Development and Application of Innovation Management from Regional expansion to Global Growth, 3379-3383 (2018) 